\begin{tabular}{|c|c|c|}
\hline $\begin{array}{l}\text { PKS } \\
\text { PUBLIC } \\
\text { KNOWLEDGE } \\
\text { PROJECT }\end{array}$ & $\begin{array}{c}\text { REVISTA DE GEOGRAFIA } \\
\text { (RECIFE) } \\
\text { http://ww.revista.ufpe.br/revistageografia }\end{array}$ & $\begin{array}{l}\text { OJS } \\
\frac{\text { OPEN }}{\text { OPENAL }} \\
\text { SYSTEMS }\end{array}$ \\
\hline
\end{tabular}

\title{
IMPACTOS AMBIENTAIS NA QUALIDADE DA ÁGUA DA NASCENTE PAU AMARELO EM GARANHUNS-PE
}

\author{
Antonio Benevides Soares ${ }^{1}$, Adriano Lima Troleis ${ }^{2}$ \\ ${ }^{1}$ Mestre em Geografia pela Universidade Federal do Rio Grande do Norte. Email: a-bene2011 @ hotmail.com \\ ${ }^{2}$ Professor do Centro de Ciências Humanas, Letras e Artes da Universidade Federal do Rio grande do Norte. \\ Email: adrianotroleis@gmail.com
}

Artigo recebido em 09/05/2016 e aceito em 13/08/2017

\begin{abstract}
RESUMO
A cidade de Garanhuns passa por um intenso processo de expansão urbana que tem provocado severos impactos ao meio natural, sobretudo em nascentes dotadas de grande valor histórico e ambiental. Diante disso, o presente estudo teve como objetivo analisar os impactos ambientais na qualidade da água da nascente Pau Amarelo, localizada no município de Garanhuns-PE. Tal análise se deu por meio da utilização do Índice de Impacto Ambiental em Nascentes - IIAN e do monitoramento da qualidade da água proveniente da nascente, utilizando os parâmetros Oxigênio Dissolvido, Demanda Bioquímica de Oxigênio, Nitrato e Coliformes Totais e Fecais. Através do IIAN, constatou-se um contexto de impactos ambientais extremamente grave com problemáticas que remetem ao total desrespeito à legislação ambiental vigente. Em relação à qualidade da água da nascente, a análise dos laudos realizada com base na Resolução n 357/2005 do CONAMA mostra resultados gravíssimos na nascente monitorada, cuja qualidade da água encontra-se extremamente prejudicada.
\end{abstract}

Palavras-chave: Ambiente urbano; Qualidade de água; Nascentes; Garanhuns-PE.

\section{ENVIRONMENTAL IMPACTS ON WATER QUALITY FROM THE SPRING PAU AMARELO}

\begin{abstract}
The city of Garanhuns undergoes an intense process of urban sprawl that has caused severe impacts to the natural environment, especially in springs endowed with great historical and environmental value. Therefore, this study aimed to analyze the social and environmental impacts on spring water quality Pau Amarelo, located in Garanhuns-PE. This analysis was performed by using the Environmental Impact Index in Springs - EIIS and monitoring quality from the spring water, using the parameters Dissolved Oxygen, Biochemical Oxygen Demand, Nitrate, Total Coliform and Coliform Faecal. Through the index, an extremely serious context of social and environmental impacts was founded with great problematic that refer to the total disregard for environmental regulations. Regarding the spring water quality, analysis of reports made on the basis of Resolution No. $357 / 2005$ of CONAMA shows very serious results in the monitored spring, whose water quality is greatly impaired.
\end{abstract}

Key-words: Urban Environment; Water Quality; Water Springs; Garanhuns-PE.

\section{INTRODUÇÃO}

A partir da metade do século XX, grande parte das cidades brasileiras apresentaram expressiva urbanização e assim passaram a ser o lócus do progresso, atraindo imigrantes e se 
expandindo desordenadamente, decorrendo em diversos problemas ambientais em seu espaço urbano.Tal crescimento urbano ocorreu de forma desigual, mal planejado e poucas vezes executado nas raras vezes em que foi planejado. Nesse sentido, houve uma grande transformação quantitativa, implicando transformações qualitativas profundas no espaço urbano. Assim, a expressão socioespacial da grande maioria das cidades brasileiras reflete a desigualdade social distribuída de forma espacialmente distinta com os pobres relegados a áreas degradadas, sem infraestrutura e não raro sujeitos a perigos naturais (DÉAK; SCHIFFER, 1999; SOUZA, 2010; MENDONÇA, 2004).

Essa lógica de expansão urbana desordenada, desigual e poluente aconteceu também em importantes cidades do interior de Pernambuco das quais tomamos como foco do presente estudo Garanhuns, município que teve seu território ocupado inicialmente pela localização geográfica estratégica e pelas condições naturais favoráveis com clima ameno e abundância de recursos hídricos devido a sua localização serrana com grande quantidade de nascentes. Assim surgiu o povoamento, que foi elevado à categoria de vila em 1811 e à de cidade em 1879. A partir de 1887 , com a vinda da linha férrea, a cidade se desenvolveu rapidamente e passou a utilizar intensamente as águas de nascentes próximas para abastecimento, e já na década de 1920, possuía sistema de encanamento para abastecimento público com água da nascente Pau Pombo que, nos anos seguintes, foi ampliado para as nascentes Vila Maria e Pau Amarelo. O uso das nascentes foi feito até 1970, quando foi suspenso tendo como uma das razões as suspeitas de contaminação por esgotos advindos das habitações que cada vez mais se aproximavam dos mananciais.

No início da década de 1970, a ferrovia foi desativada, porém várias rodovias já haviam sido inauguradas e propiciaram uma maior fluidez à região, dinamizando a economia e favorecendo o crescimento do tecido urbano, que continuou a se expandir com intensidade. Assim, diversos problemas ambientais surgem e se intensificam no município, dentre eles condições precárias de moradia em áreas impróprias, aterramento e poluição de nascentes que outrora foram utilizadas para abastecimento da população e que também foram importantes para a economia do município, pois forneciam água para a segunda maior indústria extrativista de água mineral do estado nos anos 1950 (IBGE, 1959).

$\mathrm{Na}$ atualidade, o município vive uma nova fase de intensificação do crescimento urbano em razão de uma importante expansão universitária que contribui significativamente, junto com a vanguarda do setor de serviços, para uma intensa especulação imobiliária e a produção acelerada de um espaço urbano desordenado e desigual. Assim, são visíveis 
condições de moradia precárias e insalubres em áreas inapropriadas no entorno de nascentes, caracterizando uma forte pressão sobre os mananciais existentes no meio urbano.

Diante do exposto, definiu-se como objetivo deste artigo analisar a problemática ambiental decorrente da expansão urbana no entorno da nascente Pau Amarelo. Para alcançar tal objetivo, definiram-se os seguintes objetivos específicos: Analisar, de forma qualitativa, o grau de impacto a que a nascente estudada está exposta, através da avaliação de elementoschave na identificação de impactos ambientais e suas consequências sobre a qualidade da nascente; Monitorar a qualidade da água superficial proveniente da nascente e analisar os resultados com base na Resolução no 357/2005 do Conselho Nacional de Meio Ambiente CONAMA; Propor medidas mitigadoras para as problemáticas analisadas.

A nascente alvo do presente estudo foi escolhida em razão da sua importância histórica e ambiental, sendo uma das nascentes fundamentais no estabelecimento e no desenvolvimento do núcleo urbano de Garanhuns, bem como para o abastecimento da cidade durante mais de quarenta anos. A nascente Pau Amarelo pertence à bacia do Rio Mundaú e a realização do estudo proposto remete-se à necessidade de contribuir com o cumprimento do Plano Diretor de Garanhuns no tocante à produção de análises, diagnósticos e produtos cartográficos que subsidiem a proteção das Áreas de Preservação Permanente (APP) e que contribuam com a efetivação de outros instrumentos de proteção e recuperação ambiental das nascentes propostos no Plano Diretor em vigor que até o momento não foram realizados pelo poder público.

Os estudos sobre nascentes são escassos, em geral, no tocante aos recursos hídricos há um intenso predomínio de trabalhos que priorizam o rio ou a bacia como um todo, devido à sua importância como unidade de planejamento, havendo uma lacuna que precisa ser preenchida, uma vez que as nascentes são de grande importância para o abastecimento, além de serem fundamentais para a manutenção dos rios e, consequentemente, para a bacia hidrográfica.

A Figura 01, a seguir, mostra a localização das nascentes existentes no núcleo urbano do município de Garanhuns com destaque para a nascente alvo do presente estudo. $\mathrm{O}$ município de Garanhuns localiza-se no agreste pernambucano a 228,8 km da capital Recife. Possui uma população estimada pelo IBGE (2015) em 136.949 habitantes, em termos econômicos, é um dos mais relevantes municípios do estado se destacando como polo universitário e na liderança do setor de serviços na microrregião Agreste Meridional, se caracteriza como "área de exceção" climática e faunística devido ao feito orográfico 
apresentando brejos e abundância de recursos hídricos, encontrando-se inserido na Bacia Hidrográfica do Rio Mundaú, do qual possui várias nascentes sendo a nascente Pau Amarelo uma das principais.

Figura 01-Localização da nascente Pau Amarelo

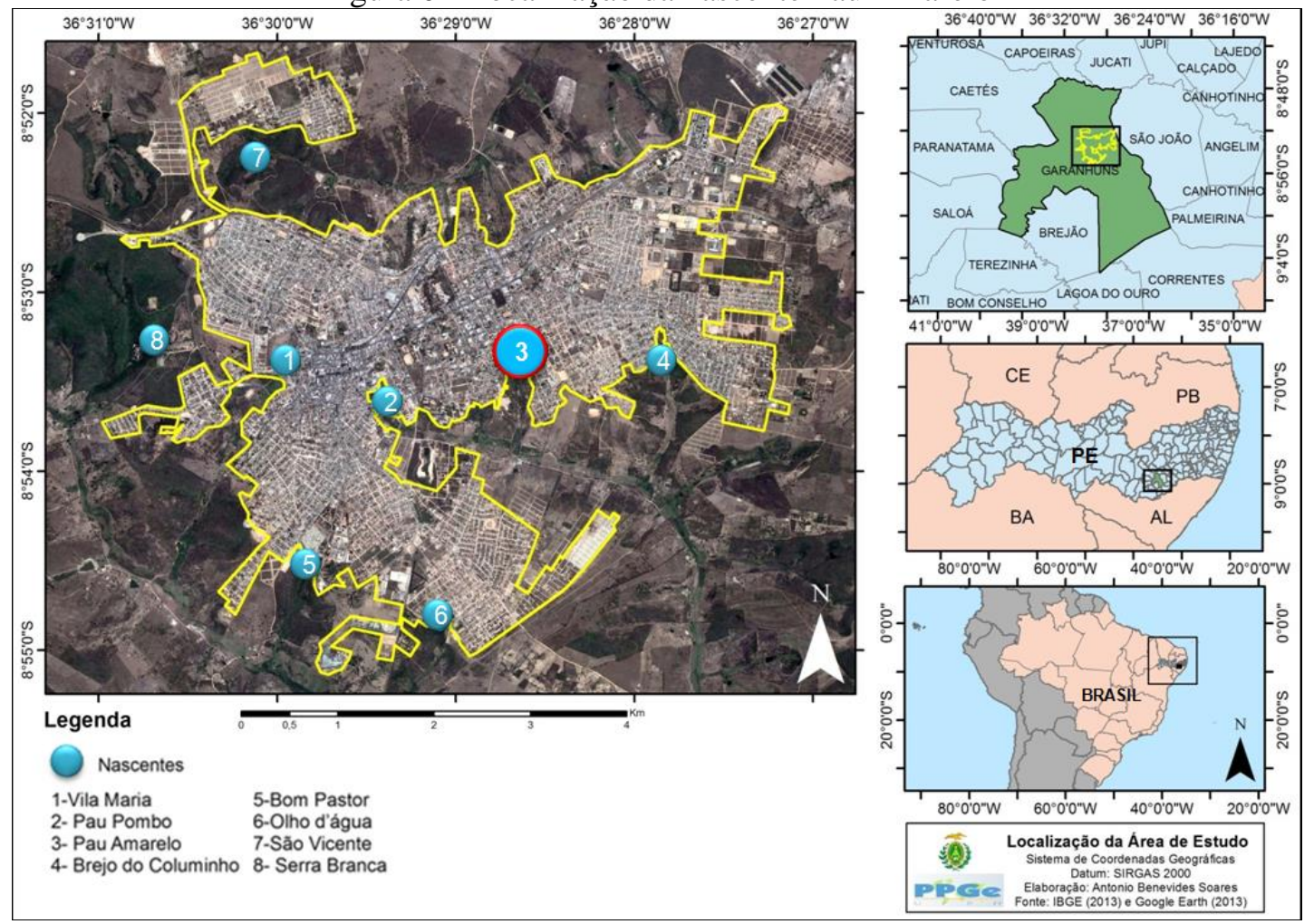

Fonte: Elaborado com base em dados do IBGE (2013) e Google Earth (2013).

\section{ASPECTOS CONCEITUAIS E METODOLÓGICOS}

\subsection{Conceitos de nascente}

O que se verifica de maneira imediata, em relação ao conceito de nascente, é que há uma forte polissemia da mesma maneira que acontece com conceitos clássicos da ciência geográfica como espaço e região, por exemplo, onde o uso por diversas áreas de conhecimento e pelo senso comum naturaliza o conceito, deixando seu significado nebuloso e impreciso. No tocante ao conceito de nascente, nota-se que cada campo de estudo, que, por razões distintas, trabalha direta ou indiretamente com nascentes, utiliza conceitos diferentes dependendo do foco do estudo, do local em que o estudo é desenvolvido e dos condicionantes do meio físico de cada região.

No Quadro 01, elenca-se uma série de conceitos de nascente identificados durante a pesquisa e que demonstram a pluralidade de olhares sobre o termo nascente bem como a polissemia que alguns aspectos ou o próprio conceito pode assumir. 
Quadro 01- Conceitos de nascente utilizados por diversos autores.

\begin{tabular}{|c|c|}
\hline AUTOR & CONCEITO \\
\hline CONAMA (2002) & $\begin{array}{l}\text { Nascente ou olho d'água: local onde aflora naturalmente, mesmo que de forma } \\
\text { intermitente, a água subterrânea. }\end{array}$ \\
\hline $\begin{array}{l}\text { Código Florestal } \\
\text { (BRASIL, 2012) }\end{array}$ & $\begin{array}{l}\text { Afloramento natural do lençol freático que apresenta perenidade e dá início a um } \\
\text { curso d'água. }\end{array}$ \\
\hline $\begin{array}{lll}\text { Todd } & \text { e } & \text { Mays } \\
(2005) & \end{array}$ & $\begin{array}{l}\text { Uma nascente é uma descarga concentrada de água subterrânea que aparece na } \\
\text { superfície do terreno como uma corrente de água. }\end{array}$ \\
\hline $\begin{array}{l}\text { Valente e Gomes } \\
\text { (2011) }\end{array}$ & $\begin{array}{l}\text { Nascentes são manifestações superficiais de lençóis subterrâneos, dando origem a } \\
\text { curso d'água. }\end{array}$ \\
\hline Davis (1966) & $\begin{array}{l}\text { Qualquer descarga de água natural na superfície grande o suficiente para fluir em } \\
\text { um pequeno riacho pode ser chamada de uma nascente. Descarga menor do que } \\
\text { essa é chamada de superfície de infiltração. }\end{array}$ \\
\hline $\begin{array}{l}\text { Guerra e Guerra } \\
(1997)\end{array}$ & $\begin{array}{l}\text { Área onde existem os olhos d'água que dão origem a um curso fluvial; é o oposto } \\
\text { de foz. Não se deve pensar que a cabeceira seja um lugar bem definido. Por } \\
\text { vezes, ela constitui uma verdadeira área, e nesse caso surge uma série de } \\
\text { problemas não menos difíceis, como o da escolha de um critério para a } \\
\text { determinação do rio principal. As cabeceiras são também denominadas de: } \\
\text { nascente, fonte, minadouro, mina, lacrimal, pantanal manancial etc. }\end{array}$ \\
\hline Pinto et al (2004) & $\begin{array}{l}\text { Cada início dos tributários. Existem nascentes pontuais e difusas, as nascentes } \\
\text { pontuais apresentam a ocorrência do fluxo d'água em um único ponto do terreno } \\
\text { e as difusas quando há vários olhos d'água. }\end{array}$ \\
\hline $\begin{array}{l}\text { Gomes et al } \\
(2005)\end{array}$ & $\begin{array}{l}\text { A nascente do rio ou riacho é a fonte situada no limite do afloramento do } \\
\text { aquífero. A cabeceira é o ponto onde nasce o curso d'água, não possuindo lugar } \\
\text { bem definido, pode ser formada por uma área. }\end{array}$ \\
\hline $\begin{array}{l}\text { Felippe et al., } \\
\text { (2009) }\end{array}$ & $\begin{array}{l}\text { Nascente é um sistema ambiental marcado por uma feição geomorfológica ou } \\
\text { estrutura geológica em que ocorre a exfiltração da água de modo temporário ou } \\
\text { perene, formando canais de drenagem a jusante. }\end{array}$ \\
\hline Bryan (1919) & $\begin{array}{l}\text { Uma nascente é um lugar onde a água emana do solo e flui ou onde se encontra } \\
\text { em piscinas que são continuamente reabastecidas pelo fundo, exceto as aberturas } \\
\text { totalmente artificiais, como poços artesianos, que não são consideradas como } \\
\text { nascentes. }\end{array}$ \\
\hline
\end{tabular}

Fonte: Os autores citados.

A partir do exposto no quadro 01, vê-se que a noção de nascente é inseparável do processo de surgência da água subterrânea para a superfície. Assim, definimos nascente como sendo o processo de surgência ou exfiltração da água subterrânea para a superfície, independentemente de formar córregos, represamentos ou da exfiltração ocorrer em um corpo de água superficial. Essa surgência ou exfiltração pode acontecer de forma espraiada, dando origem ao que se chama de nascente difusa ou de forma pontual, o que se pode chamar de olho d'água. A surgência ou exfiltração pode ocorrer com diferentes tipos e variação de vazão, podendo haver nascentes perenes e intermitentes, isso significa dizer que mesmo sem surgência de água durante períodos de seca é possível considerar a existência de nascentes. Nascentes não devem ser vistas apenas como o processo de exfiltração, mas também como partes de um sistema complexo que envolve aspectos climatológicos, geológicos e geomorfológicos extremamente importantes para a manutenção e existência das mesmas. 
No território do município de Garanhuns, a maioria das nascentes é de origem freática, muitas com vazão perene e com tipo de exfiltração difusa, surgindo no fundo dos vales profundos que também possuem algumas poucas nascentes de exfiltração pontual nas suas encostas. Algumas nascentes existentes no município inclusive foram consideradas de extrema relevância no passado por possuírem propriedades minerais diferenciadas.

\subsection{Etapas e procedimentos metodológicos da pesquisa}

Os corpos hídricos presentes em espaços urbanos estão submetidos a um contexto que favorece a degradação de sua qualidade bem como o comprometimento de sua quantidade, porém os casos de nascentes presentes nesses espaços são especialmente preocupantes, pois estas fazem parte de sistemas ambientais singulares que possuem grande sensibilidade e, portanto também maior fragilidade. Nesse sentido, analisar o contexto urbano em que essas nascentes estão inseridas é de fundamental importância na verificação da proteção ambiental das mesmas.

Neste artigo, serão analisados e avaliados os impactos ambientais considerando o contexto socioambiental do entorno da nascente Pau Amarelo, presente no centro urbano de Garanhuns-PE. Os impactos ambientais na nascente serão avaliados utilizando-se o Índice de Impacto Ambiental em Nascentes - IIAN, conforme operacionalizado por Felippe e Magalhães Junior (2012), os quais se basearam em Gomes et al (2005) e nas adaptações promovidas por Felippe (2009) e Paraguaçu et al (2010). Assim, o IIAN utilizado neste trabalho é uma releitura e adaptação da avaliação de nascentes proposta por Gomes et al (2005), que tem como base a Classificação do Grau de Impacto de Nascente do Sistema Nacional de Informação de Recursos Hídricos de Portugal e no Guia de Avaliação da Qualidade das Águas feito pela Rede das Águas. Mediante a utilização do IIAN, objetiva-se a classificação e a verificação de forma qualitativa do grau de impacto a que a nascente estudada está exposta.

O IIAN consiste em uma técnica de "[...] avaliação sensorial - macroscópica - e comparativa de alguns elementos-chave na identificação de impactos ambientais e suas conseqüências sobre a qualidade das nascentes" (FELIPPE, 2009, p. 130). Esses elementoschave são parâmetros macroscópicos avaliados observando-se as características de uso e ocupação no entorno da nascente a ser estudada (Quadro 02). A essas características se atribui uma qualificação "bom", "médio" ou "ruim", que corresponde aos valores 1, 2 e 3, 
respectivamente; a somatória dos valores de todos os parâmetros macroscópicos analisados constitui o Índice de Impacto Ambiental em Nascentes - IIAN em que as classes de pontuação correspondem a graus de proteção diferenciados. Dessa forma, uma nascente que obtiver abaixo de 21 pontos será considerada com péssimo grau de proteção, por outro lado, caso obtenha entre 31 e 33 pontos, será considerada como possuindo um ótimo grau de proteção, podendo haver resultados intermediários onde, quanto menor a pontuação, mais grave é o contexto de impactos que afetam a nascente.

Quadro 02- Metodologia do índice de impacto ambiental macroscópico em nascentes.

\begin{tabular}{|c|c|c|c|}
\hline \multirow[t]{2}{*}{ Parâmetro Macroscópico } & \multicolumn{3}{|c|}{ Qualificação } \\
\hline & Ruim (1) & Médio (2) & Bom (3) \\
\hline Cor da água & Escura & Clara & Transparente \\
\hline Odor da água & Forte & Com odor & Não há \\
\hline Lixo ao redor da nascente & Muito & Pouco & Não há \\
\hline Materiais flutuantes & Muito & Pouco & Não há \\
\hline Espumas & Muito & Pouco & Não há \\
\hline Óleos & Muito & Pouco & Não há \\
\hline Esgoto na nascente & Visível & Provável & Não há \\
\hline Vegetação & Degradada ou ausente & Alterada & Bom estado \\
\hline Usos da nascente & Constante & Esporádico & Não há \\
\hline Acessibilidade & Fácil & Difícil & Sem acesso \\
\hline $\begin{array}{l}\text { Equipamentos de } \\
\text { Infraestrutura }\end{array}$ & A menos de 50 metros & Entre 50 e $100 \mathrm{~m}$ & A mais de $100 \mathrm{~m}$ \\
\hline \multicolumn{4}{|c|}{ Classificação das nascentes quanto aos impactos macroscópicos } \\
\hline Classe & Grau de proteção & \multicolumn{2}{|c|}{ Pontuação } \\
\hline A & Ótimo & \multicolumn{2}{|c|}{$31-33$} \\
\hline $\mathrm{B}$ & Bom & \multicolumn{2}{|c|}{$28-30$} \\
\hline $\mathrm{C}$ & Razoável & \multicolumn{2}{|c|}{$25-27$} \\
\hline $\mathrm{D}$ & Ruim & \multicolumn{2}{|c|}{$22-24$} \\
\hline $\mathrm{E}$ & Péssimo & \multicolumn{2}{|c|}{ Abaixo de 21} \\
\hline
\end{tabular}

Fonte: Elaborado pelos autores com base em Felippe e Magalhães Junior (2012).

Os parâmetros selecionados levam em conta a existência de vários fatores que alteram a qualidade da água da nascente e do córrego originado por ela, assim como consideram a proteção da mesma em relação à influência externa.

Considerando que analisar os impactos macroscópicos presentes no entorno da nascente é insuficiente para uma análise completa dos danos ambientais ao manancial, o tópico 3.2 deste artigo é dedicado à análise da qualidade das águas provenientes da nascente Pau Amarelo. Nesse sentido, foram realizadas coletas e análise laboratorial de amostras de água da referida nascente nos meses de abril, julho, agosto, outubro e dezembro de 2013 e nos meses de fevereiro e abril de 2014. O horizonte temporal de coleta amostral foi definido para observar o comportamento dos parâmetros em diferentes períodos sazonais e assim verificar 
os meses em que houve concentração ou diluição de poluentes na água. Dentre os vários parâmetros de qualidade de água existentes foram selecionados para monitoramento e análise os seguintes: Oxigênio Dissolvido, Demanda Bioquímica de Oxigênio, Nitrato, Condutividade Elétrica, Coliformes Totais e Fecais.

A escolha desses parâmetros se deu em razão da alta relevância dos mesmos como indicadores do grau de poluição e contaminação das águas. A análise dos parâmetros teve como referência a Resolução n 357/05 do CONAMA onde constam os usos permissíveis de acordo com a qualidade da água expressa pelos resultados dos parâmetros. No entanto, para os parâmetros Condutividade Elétrica e Coliforme Total as análises tiveram como referência CONAMA (1986) e Brasil (2004).

A metodologia de coleta das amostras das águas analisadas é de fundamental importância para a confiabilidade dos resultados da análise laboratorial, por isso foram realizadas seguindo as recomendações do Guia nacional de coleta e preservação de amostras/CETESB (BRANDÃO, 2011) referentes a procedimentos de coleta e amostragem de águas brutas. Assim, a coleta das amostras foi feita sempre no mesmo local, seguindo sempre o mesmo procedimento, utilizando luvas para evitar contato que pudesse modificar as características da amostra colhida, recipientes de polietileno e sacos esterilizados para amostragem, fornecidos pelo Laboratório de Análises de Alimentos e Águas (LAMEN), seguindo procedimentos específicos de coleta de amostras para ensaios químicos e microbiológicos em águas brutas, assim como as diretrizes de acondicionamento, transporte e armazenamento de amostras, conforme especifica a CETESB (BRANDÃO, 2011), em consonância com as orientações da American Public Health Association (APHA).

Após as coletas, as amostras foram enviadas ao laboratório privado LAMEN para detecção analítica e através dos laudos fornecidos foi possível analisar e interpretar os resultados de cada parâmetro tendo como referência a Resolução no 357/2005 do CONAMA em relação aos usos permitidos para cada classe onde, quanto maior a classe, menos exigente é o uso (Quadro 03). A análise dos parâmetros neste trabalho teve como referência de qualidade mínima aceitável para a classe II, pois as classes III e IV dizem respeito a águas de qualidade muito alterada que são inaceitáveis para águas provenientes de nascentes, mesmo diante das pressões sofridas por esses corpos hídricos no contexto urbano. Com isso busca-se mensurar a poluição causada pelos impactos urbanos e suas possíveis consequências para o corpo hídrico em si e para os usuários diretos e indiretos. 
Quadro 03- Classificação dos usos das águas doces e limites das classes especial, I, II, III e IV para os parâmetros analisados.

\begin{tabular}{|c|c|c|c|c|c|}
\hline \multicolumn{5}{|c|}{ Classificação dos usos das águas doces segundo a Resolução 357/2005 do CONAMA } & Classe \\
\hline \multicolumn{5}{|c|}{$\begin{array}{l}\text { a) ao abastecimento para consumo humano, com desinfecção; } \\
\text { b) à preservação do equilíbrio natural das comunidades aquáticas; e, } \\
\text { c) à preservação dos ambientes aquáticos em unidades de conservação de proteção integral. }\end{array}$} & Especial \\
\hline \multicolumn{5}{|c|}{$\begin{array}{l}\text { a) ao abastecimento para consumo humano, após tratamento simplificado; } \\
\text { b) à proteçãa das comunidades aquáticas; } \\
\text { c) à recreação de contato primário, conforme Resolução CONAMA no 274, de 2000; } \\
\text { d) à irrigação de hortaliças que são consumidas cruas e de frutas que se desenvolvam rentes } \\
\text { ao solo e que sejam ingeridas cruas sem remoção de película; e } \\
\text { e) à proteção das comunidades aquáticas em Terras Indígenas. }\end{array}$} & \begin{tabular}{l|l} 
Classe I \\
\end{tabular} \\
\hline \multicolumn{5}{|c|}{$\begin{array}{l}\text { a) ao abastecimento para consumo humano, após tratamento convencional; } \\
\text { b) à proteção das comunidades aquáticas; } \\
\text { c) à recreação de contato primário, conforme Resolução CONAMA no } 274 \text {, de } 2000 \text {; } \\
\text { d) à irrigação de hortaliças, plantas frutíferas e de parques, jardins, campos de esporte e } \\
\text { lazer, com os quais o público possa vir a ter contato direto; e } \\
\text { e) à aquicultura e à atividade de pesca }\end{array}$} & $\begin{array}{l}\text { Classe } \\
\text { II } \\
\end{array}$ \\
\hline \multicolumn{5}{|c|}{$\begin{array}{l}\text { a) ao abastecimento para consumo humano, após tratamento convencional ou avançado; } \\
\text { b) à irrigação de culturas arbóreas, cerealíferas e forrageiras; } \\
\text { c) à pesca amadora; } \\
\text { d) à recreação de contato secundário; e } \\
\text { e) à dessedentação de animais. }\end{array}$} & $\begin{array}{l}\text { Classe } \\
\text { III }\end{array}$ \\
\hline \multicolumn{5}{|l|}{$\begin{array}{l}\text { a) à navegação; e } \\
\text { b) à harmonia paisagística }\end{array}$} & $\begin{array}{l}\text { Classe } \\
\text { IV }\end{array}$ \\
\hline \multirow[t]{2}{*}{ Parâmetros } & \multicolumn{5}{|l|}{ Classes } \\
\hline & Especial & Classe I & Classe II & Classe III & Classe IV \\
\hline $\mathrm{OD}\left(\mathrm{mg} / \mathrm{L} \mathrm{O}^{2}\right)$ & Não define & $>6,0$ & $>5,0$ & $>4,0$ & $>2,0$ \\
\hline $\mathrm{DBO}\left(\mathrm{mg} / \mathrm{L} \mathrm{O}^{2}\right)$ & Ausente & 3,0 & 5,0 & 10 & - \\
\hline Nitrato $(\mathrm{mg} / \mathrm{L} \mathrm{N})$ & Ausente & 10,0 & 10,0 & 10,0 & - \\
\hline $\begin{array}{l}\text { Coliformes } \\
\text { (N.M.P./100ml) }\end{array}$ & Ausente & 200 & 1.000 & 4.000 & - \\
\hline $\begin{array}{l}\text { Coliformes } \\
\text { (N.M.P./100ml) }\end{array}$ & Não define & Não define & Não define & Não define & Não define \\
\hline $\begin{array}{l}\text { Condutividade } \\
(\mu \mathrm{S} / \mathrm{cm})\end{array}$ & Não define & Não define & Não define & Não define & Não define \\
\hline
\end{tabular}

Fonte: Resolução do CONAMA nº 357/2005.

Em relação ao parâmetro Coliforme Total, a Resolução n 357/05 do CONAMA não define limites. No entanto, o Coliforme Total ainda é amplamente utilizado justamente por ser um excelente parâmetro de qualidade de água. Assim, para fins analíticos, serão utilizados os limites da Resolução do CONAMA nº 020/1986 já revogada, porém onde constam limites plausíveis. Já para o parâmetro Condutividade Elétrica, baseados em Brasil (2004) e em Brigante e Espíndola (2003), consideramos $100 \mu \mathrm{S} / \mathrm{cm}$ como limite de referência para as análises, uma vez que as águas não poluídas dificilmente apresentam resultados acima disso. 


\section{IMPACTOS AMBIENTAIS NA QUALIDADE DA ÁGUA DA NASCENTE PAU} AMARELO

\subsection{Análise do contexto ambiental da nascente Pau Amarelo}

A nascente Pau Amarelo localiza-se no bairro Heliópolis, a leste do centro da cidade de Garanhuns, apresenta exfiltração difusa com fluxo de vazão perene e ocorre no fundo do Vale da Liberdade, vale que divide o bairro Heliópolis em duas partes, uma conhecida pelo nome homônimo ao do bairro (oeste) e outra conhecida popularmente como Liberdade (leste). A nascente foi usada desde a década de 1930 até o início dos anos 1970, para o abastecimento de água da cidade, no entanto, em razão da grande demanda, da possibilidade de contaminação por esgotos e da obsolescência do sistema de distribuição, o abastecimento pela nascente foi substituído pelo de barragens e a área de captação foi abandonada, desde então, em razão da ocupação no seu entorno, sofre impactos ambientais continuamente.

Desde que o bairro Heliópolis foi loteado na década de 1920, somente uma pequena parte foi planejada, pois a rápida expansão da área urbana propiciada pelas vantagens que a ferrovia trouxe para a indústria, comércio e serviços de Garanhuns resultou, para o bairro, em expansão desordenada tanto por ocupações regulares (oeste) quanto irregulares (leste) decorrendo em contrastes socioespaciais entre a vertente oeste, com boa infraestrutura e moradores de renda alta, e a Liberdade na vertente leste, com moradores de baixa renda e infraestrutura precária. Nesse sentido, o Vale da Liberdade se constitui em marco espacial que separa formas espaciais qualitativamente distintas com conteúdos sociais também distintos, implicando em potencialidades de impactos ambientais diferentes assim como em fragilidades diferenciadas nas vertentes oeste e leste.

Em ambas as vertentes do Vale da Liberdade, há habitações muito próximas das encostas (Fig. 02). Nesse sentido, são habitações susceptíveis a desabamento em eventos chuvosos extremos que têm como um dos fatores potencializadores os aterramentos realizados com lixo de construção civil praticados comumente no município onde muitas residências próximas de vales têm como fundação um aterro da mesma natureza do que é apontado na Figura 03(A e B) que mostra parte da vertente do Heliópolis alterada pelo aterro. 
Figura 02- Nascente Pau Amarelo.

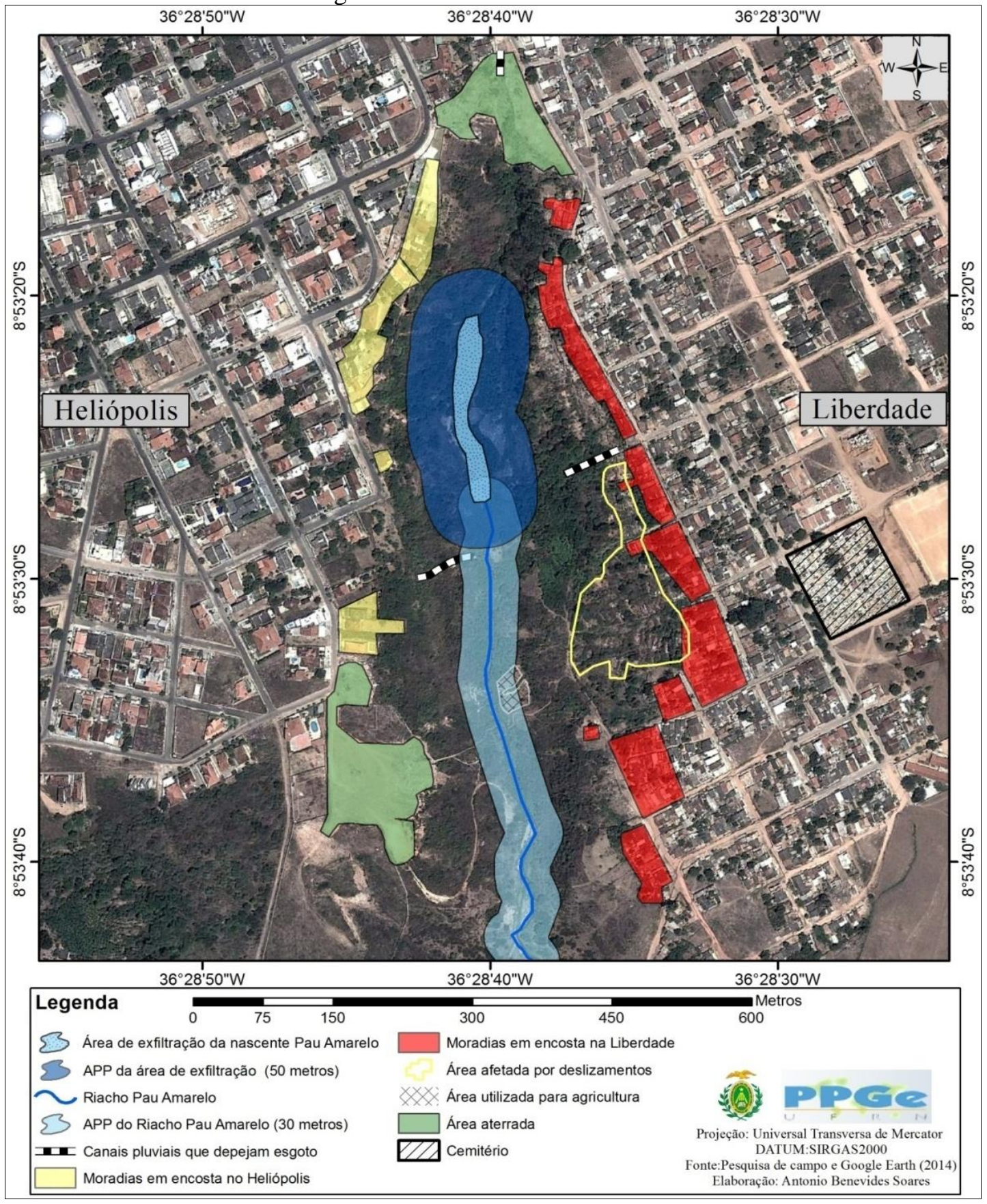

Fonte: Elaborado pelos autores.

Na encosta mostrada na Figura 03 (A e B) houve a supressão da vegetação, total modificação e exposição do solo a processos de erosão linear que em pouco tempo já resultaram no aparecimento de sulcos erosivos. Ao norte, nessa mesma vertente, já existem moradias construídas sobre aterramentos do terço superior da encosta sendo então habitações potencialmente perigosas em razão da possibilidade da ocorrência de movimentos de massa, 
situação que ainda é agravada pelas fossas dessas residências que estão muito próximas da borda da vertente. Essas moradias são gravemente nocivas para a nascente, pois modificam a drenagem das encostas, gerando erosão com consequente transporte de sedimentos para a área de exfiltração da nascente. Conforme mostra a Figura 03 ( C e D), já há uma profunda voçoroca na vertente cujo agravamento pode destruir as residências próximas, mesmo assim a construção de novas habitações próximas da vertente continua ocorrendo. Nesse sentido, constata-se uma situação preocupante onde não apenas ocorre impacto ambiental nocivo a um sistema ambiental singular como as nascentes, mas também submete-se à vida humana a graves riscos em razão da instabilidade dos aterramentos desse tipo.

$\mathrm{Na}$ vertente do lado leste do Vale da Liberdade também existem ocupações, no entanto, como é possível verificar na Figura 03 (E e F), a situação é ainda mais grave, pois as moradias foram construídas de forma precária, chegando até o terço médio da encosta com declividade que supera $45^{\circ}$, oferecendo riscos para os moradores e aumentando a possibilidade de poluição e contaminação da área de exfiltração da nascente no fundo do vale. Essas habitações promovem alteração da drenagem da encosta e transporte de sedimentos e muitas delas despejam esgoto no vale, onde é frequente o descarte de lixo doméstico que em períodos de chuva é transportado para área de exfiltração da nascente pela água proveniente de canais que destinam águas pluviais para o fundo do vale.

As habitações no entorno da nascente, além de um problema ambiental também representam um grave problema social porque apresentam condições de moradia precárias em áreas que oferecem perigos à vida humana, principalmente por deslizamentos. Como exemplo, pode-se destacar a ocorrência de fortes chuvas que atingiram a cidade no mês de junho de 2010, chegando a chover 80,2 mm em um único dia e somando um total mensal de $374,2 \mathrm{~mm}$, algo extremamente incomum para o município e muito acima da média histórica de $138,7 \mathrm{~mm}$ do mês nos últimos vinte e um anos. Diante dessas fortes chuvas, a prefeitura municipal transferiu aproximadamente 100 famílias residentes na encosta do Vale da Liberdade as quais tiveram suas residências afetadas nos deslizamentos causados pela chuva. 
Figura 03-A e B-Aterramento de encosta do Heliópolis; C-Voçoroca causada pela alteração na drenagem da vertente do Heliópolis; D- Novas construções próximas a vertente; E- Ocupações de risco em encosta com alta declividade na Liberdade; F-Processo erosivo em encosta aterrada com lixo.

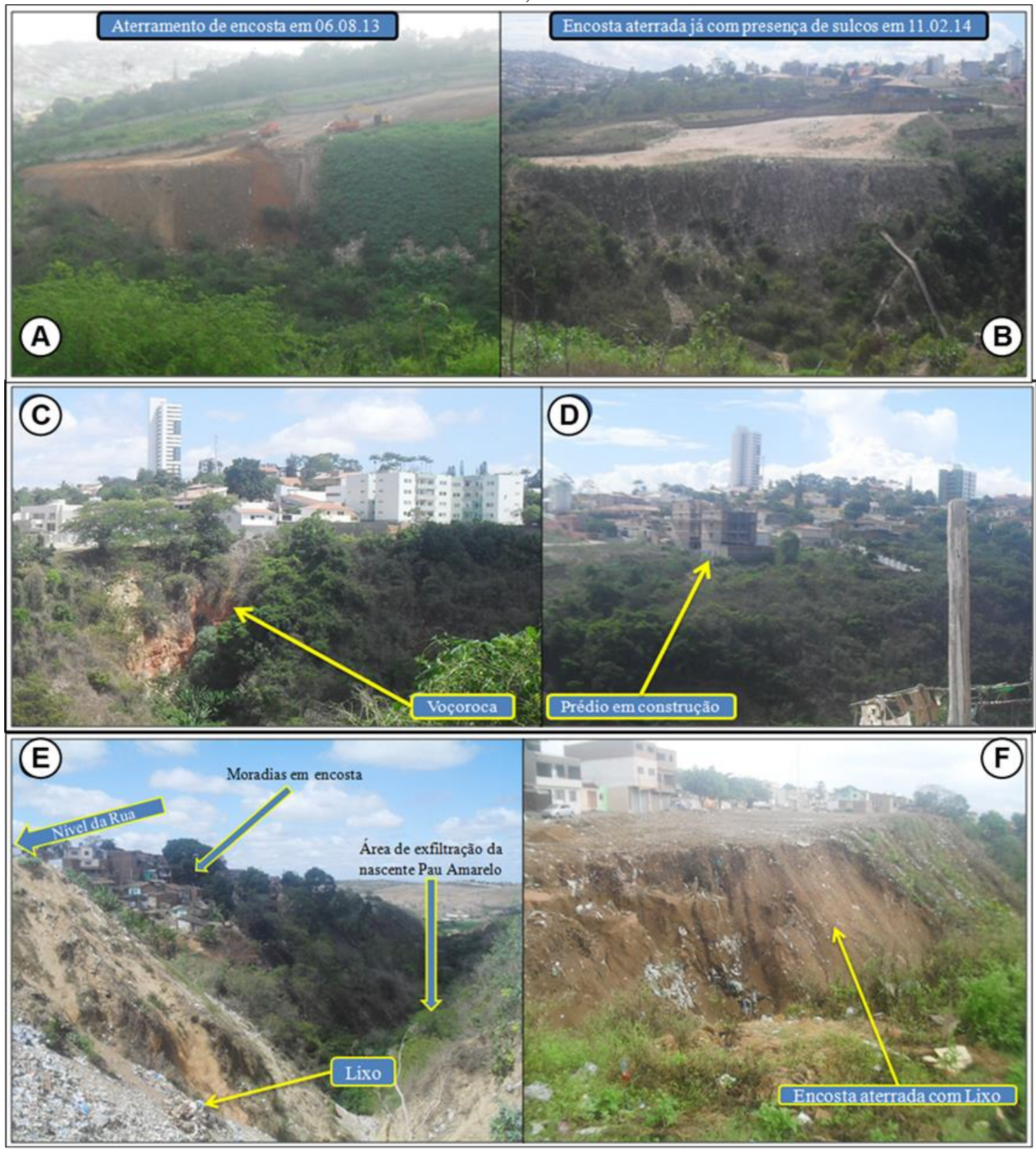

Fonte: Acervo do autor (2012,2013 e 2014).

Na Figura 04 é possível observar a área atingida por deslizamentos nas imagens de satélite de 2009, 2010 e 2013 e assim perceber as mudanças na paisagem que, em 2009, possuía residências que abrigavam as famílias atingidas; em 2010, após o evento, há apenas manchas dos escombros e em 2013, a área está sem habitações e coberta por vegetação, já que as moradias que não ruíram foram destruídas para que os moradores não retornassem. As famílias atingidas foram transferidas para casas populares em outro bairro da cidade e a 
construção de novas habitações foi impedida tanto pelo poder público quanto pelo medo de novos deslizamentos. As novas moradias para as quais os desabrigados foram transferidos localizam-se na COHAB III, um bairro que apresenta carências em relação aos serviços essenciais com destaque para transporte, educação e saneamento. Assim, os moradores saíram de uma situação precária para outra, no entanto sem o perigo de perder a vida, como havia na encosta onde habitavam. Contudo, como foi mostrado na Figura 03, ao longo da vertente do Vale da Liberdade, ainda há muitas moradias em situação de risco semelhante ao das casas que desabaram em 2010. Nesse sentido, fica claro que o poder público não atua na prevenção de desastres, mas sim em reação a eles, conforme acontece em várias cidades brasileiras como, por exemplo, Petrópolis-RJ estudada por Guerra et al (2007).

Figura 04 - Transformação da encosta onde houve deslizamento em 2010.

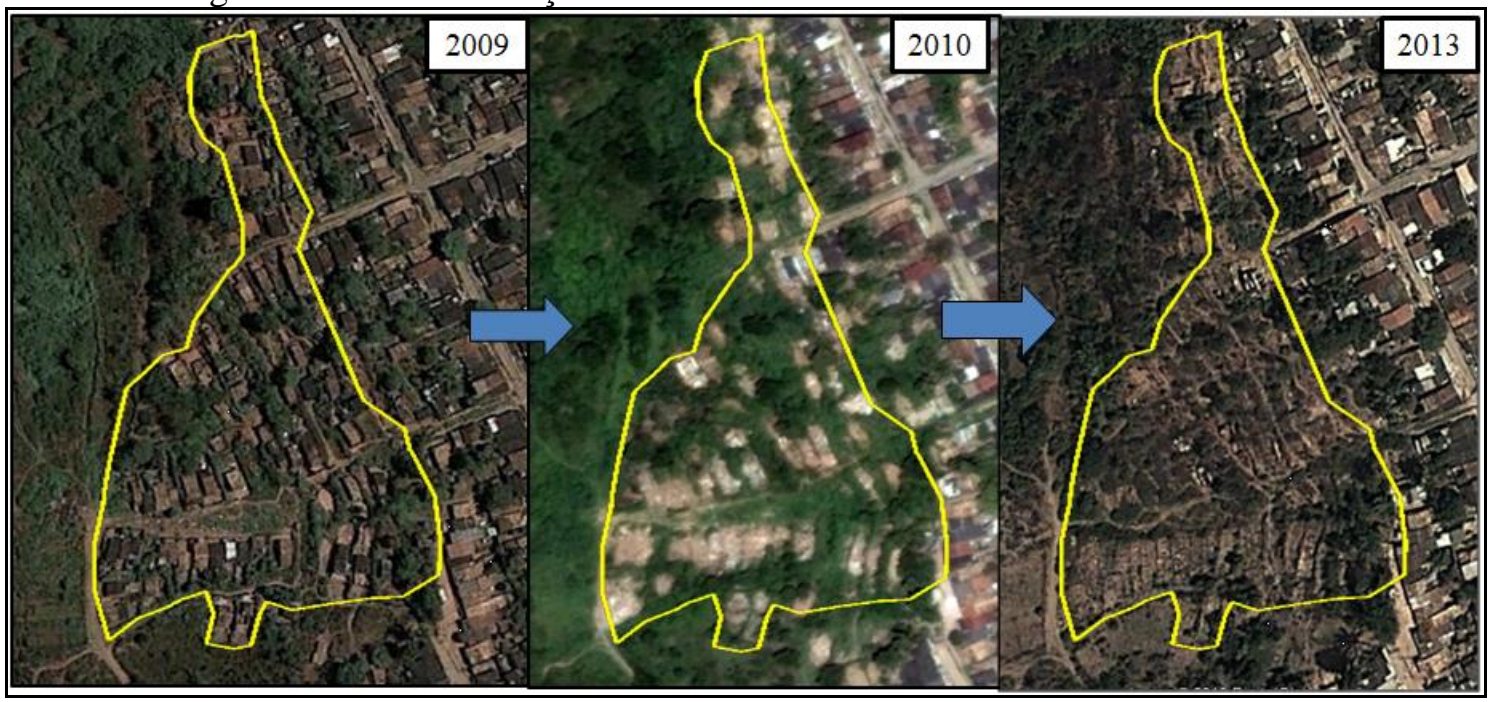

Fonte: Google Earth (2013).

A área de exfiltração da nascente Pau Amarelo é profundamente impactada pelo uso do vale para descarte de lixo doméstico e principalmente como local de bota-fora ${ }^{1}$. Esse descarte ainda hoje é feito por moradores e durante décadas foi realizado pela própria prefeitura que, além de descartar entulhos de construção civil, também recomendava que empreendedores imobiliários fizessem o mesmo. Nesse sentido, constata-se uma lógica de impactos gravemente danosa para a nascente, pois o lixo doméstico traz a possibilidade de contaminação da água por patógenos. Já os entulhos, quando ocorrem chuvas fortes, são arrastados para a área de exfiltração, aterrando e extinguindo vários veios de surgência da nascente, assim como assoreando e alterando o curso do Riacho Pau Amarelo. Esse problema

${ }^{1}$ Termo usado na construção civil para designar locais onde se destina entulhos de construções e demolições. 
foi verificado nas visitas a nascente onde se constatou alteração no curso do riacho três vezes, pois cada vez que chovia forte o canal de águas pluviais localizado na cabeceira do vale despejava água que arrastava o lixo e o entulho formando barreiras no curso do riacho e encobrindo as áreas onde havia surgências. É importante destacar que o escoamento de águas pluviais por si só já é extremamente danoso, uma vez que é o grande responsável pelo avanço do processo de expansão das voçorocas no vale e pela descaracterização e ameaça à nascente Pau Amarelo.

O despejo de águas pluviais também é particularmente danoso em razão das ligações clandestinas de esgoto doméstico existentes nesses canais, algo que acontece tanto no Heliópolis quanto na Liberdade, locais que, embora sejam contrastantes em termos do padrão construtivo das moradias e do nível de renda, são muito semelhantes na destinação do esgoto doméstico, pois várias residências em ambos os lados do vale ligam o esgoto nos canais de águas pluviais que despejam essas águas servidas na área de exfiltração da nascente Pau Amarelo (Fig. 05).

Figura 05- A- Canais de águas pluviais do Heliópolis e da Liberdade B- Esgoto proveniente dos canais do Heliópolis e da Liberdade confluindo com a água da nascente Pau Amarelo.

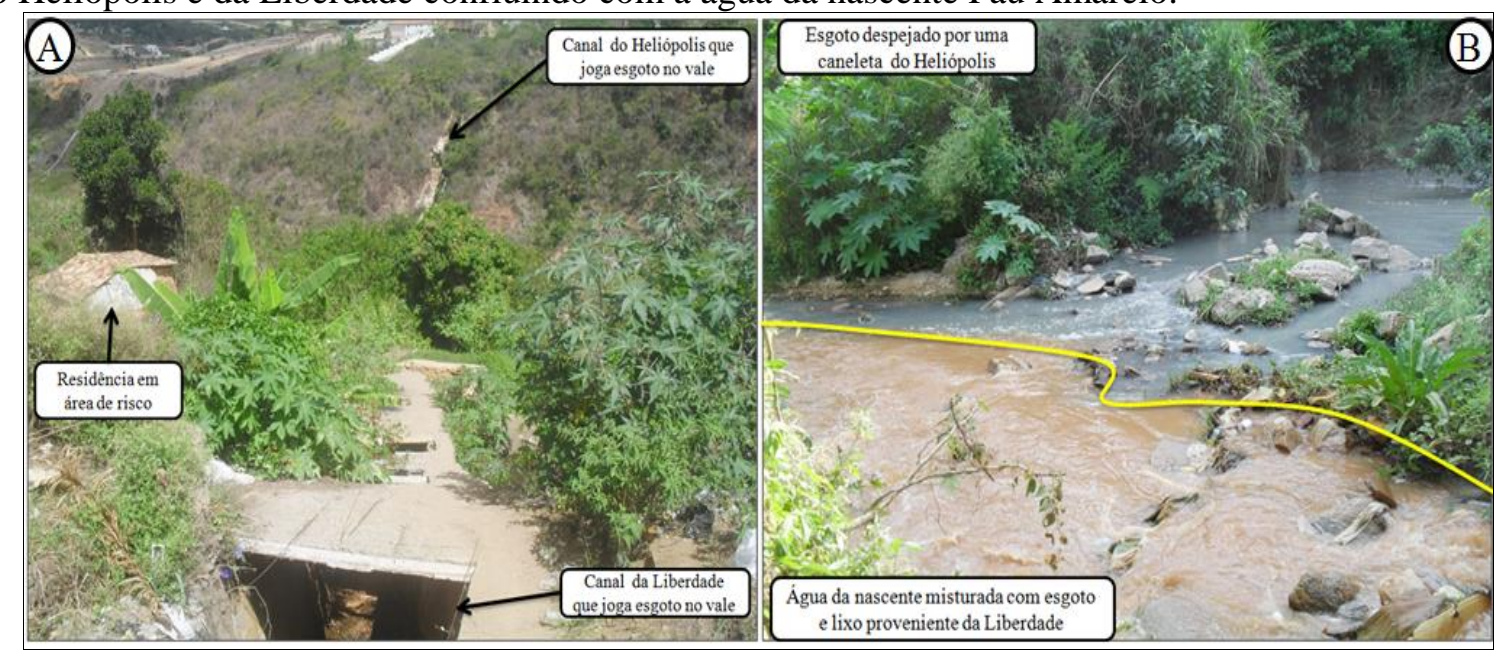

Fonte: Acervo dos autores (2013).

As águas provenientes dos canais pluviais se misturam à água exfiltrada na nascente $\mathrm{e}$ o Riacho Pau Amarelo torna-se um córrego de esgoto. Embora nem toda a área de exfiltração da nascente seja afetada, uma vez que as sugências são difusas, esse é um fato extremamente grave, pois mostra que a nascente Pau Amarelo sofre forte e contínuo impacto de esgoto de ambos os lados do Vale da Liberdade e com obras feitas pelo poder público, já que ambos os canais foram construídos pelo executivo municipal. Nesse sentido, revela-se a atuação do poder público como agente de ações contraditórias, na medida em que institui leis como o 
Plano Diretor com instrumentos legais para proteção das nascentes. No entanto, o próprio poder público desrespeita tais leis por ele criadas assim como desconsidera o Código Florestal (2012) em relação à ocupação em APP de encosta, de nascente e de curso d'água.

Considerando os parâmetros macroscópicos de análise do IIAN referentes à APP da nascente, observa-se que a nascente Pau Amarelo apresenta água de coloração escura com forte odor desagradável ocasionado pelo contínuo impacto na água por esgoto e lixo. No córrego formado pela confluência das águas dos pontos de surgência e dos canais de esgoto, além da presença de óleos e espumas na água, há toda sorte de matérias flutuantes. Em razão dessas características, as águas da nascente não possuem nenhum uso na área de surgência nem mesmo após a formação do córrego, existindo apenas o uso esporádico para recreação nos poucos pontos sem contato direto por esgoto. No entanto, é de se destacar que ao chegar na zona rural, essa água é utilizada para irrigação de diversas culturas, assim, embora haja depuração de parte da poluição, o risco de contaminação é grande especialmente no consumo de hortaliças produzidas com o uso de tal água.

No entorno da nascente a vegetação está consideravelmente alterada, apresentando muitas espécies invasoras e clareiras que em alguns pontos foram feitas por queimadas para plantio. Embora o acesso a nascente seja difícil, ocorre trânsito diário de pessoas. Também há uma grande quantidade de equipamentos de infraestrutura próximos e inadequadamente instalados que causam grande impacto ambiental à nascente. Esse é o caso dos canais que despejam esgoto e que direcionam águas pluviais para o vale, o que em períodos de chuva causa grande carreamento de sedimentos e aprofundamento do processo erosivo no ponto de queda d'água. Próximo ao vale da Liberdade também existe um cemitério que é uma fonte potencial de contaminação para o lençol freático que abastece a nascente devido ao necrochorume. Assim, considerando essas informações, o grau de proteção da nascente, segundo o IIAN, é considerado péssimo.

\subsection{Análise do comportamento dos parâmetros de qualidade de água}

Este tópico é dedicado à análise da qualidade das águas provenientes da nascente Pau Amarelo nos meses de abril, julho, agosto, outubro e dezembro de 2013 e nos meses de fevereiro e abril de 2014 referente aos parâmetros Oxigênio Dissolvido, Demanda Bioquímica de Oxigênio, Nitrato, Condutividade Elétrica, Coliformes Totais e Fecais.

O comportamento do parâmetro Oxigênio Dissolvido durante o período em análise pode ser visto no Gráfico 01, onde percebe-se que os valores do Oxigênio Dissolvido em abril 
e junho estiveram acima do limite mínimo estabelecido pela Resolução $n^{\circ}$ 357/2005 do CONAMA para as classes II e III, porém, no mês de agosto a concentração de OD foi inferior ao limite estabelecido para a classe II, mostrando maior consumo de oxigênio dissolvido na água e indicando a presença de poluição orgânica, piora na qualidade da água e maior impacto pelos esgotos lançados no vale onde a nascente se localiza. Já os meses de outubro e dezembro apresentaram, em relação aos meses anteriores, uma melhora significativa da oxigenação, excedendo mais de três vezes o mínimo exigido pela legislação para a classe II e inclusive até mesmo o limite da classe I que é mais exigente, sendo os meses em que no tocante ao parâmetro em discussão, a água coletada apresentou maior concentração de OD. Nas duas amostras coletadas em 2014 a oxigenação permaneceu em bons níveis, porém, notase considerável redução em relação às amostras coletadas em outubro e dezembro.

Gráfico 01- Comportamento do OD na nascente Pau Amarelo de abril de 2013 a abril de 2014.

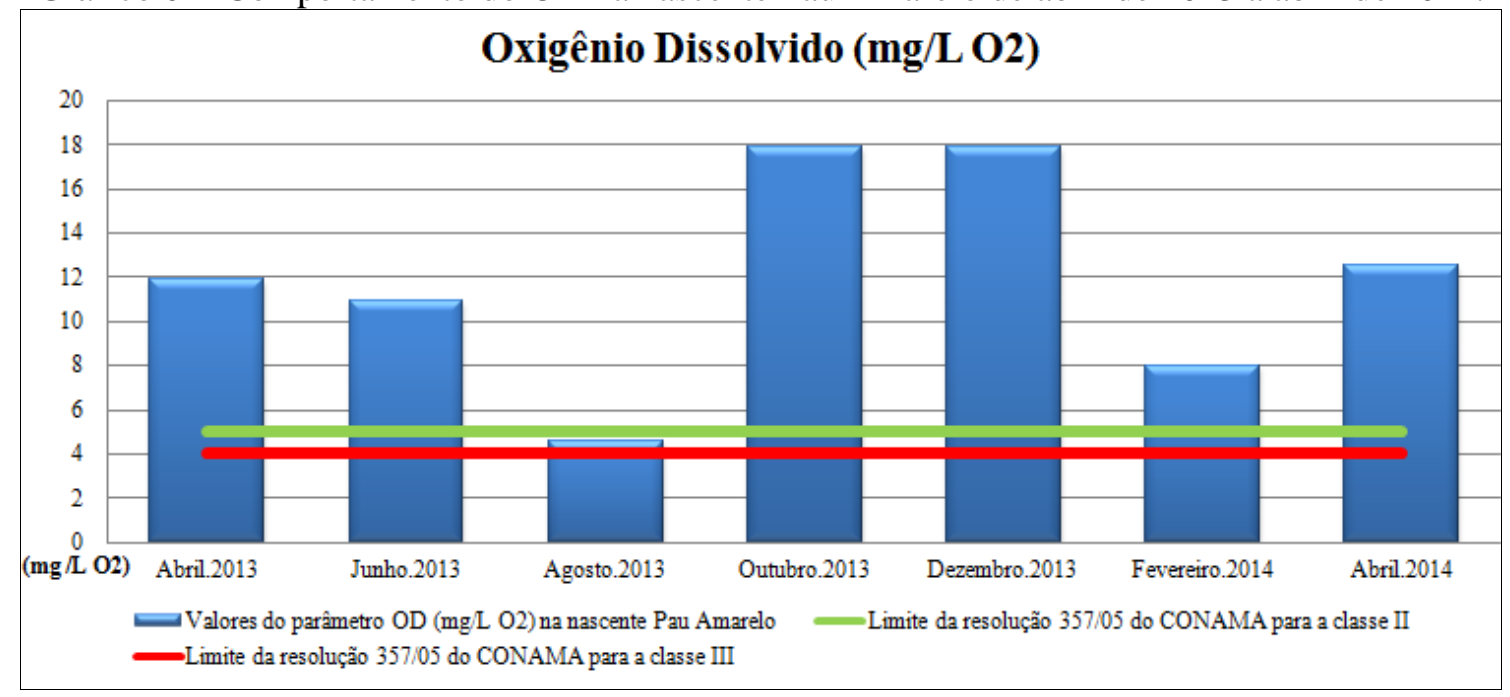

Fonte: Elaborado pelos autores com base em dados da pesquisa.

O Gráfico 02 mostra que ao longo do período monitorado, em cinco das sete amostras coletadas, o parâmetro Demanda Bioquímica de Oxigênio esteve muito superior ao limite máximo permitido pela Resolução no 357/2005 do CONAMA para as classes II e III, que é de $5 \mathrm{mg} / \mathrm{L}$ e $10 \mathrm{mg} / \mathrm{L}$, respectivamente, chegando a ser cerca de 12 vezes maior que o limite da classe II na última amostra coletada, o que corresponde extrapolar as classes III e IV, indicando que há poluição orgânica em razão da elevada demanda por oxigênio. No mês de outubro ocorreram 27,4 mm de chuvas muito próximas do período de coleta, isso pode ter influenciado na significativa redução da DBO. Em dezembro, o resultado do parâmetro em análise ficou dentro do limite definido na legislação, como não ocorreu superávit hídrico, evidencia-se que houve redução da carga de poluição, fato que também pode ter ocorrido em 
fevereiro, porém em abril de 2014 a altíssima demanda por oxigênio voltou a ocorrer, sendo a mais alta dos sete meses analisados.

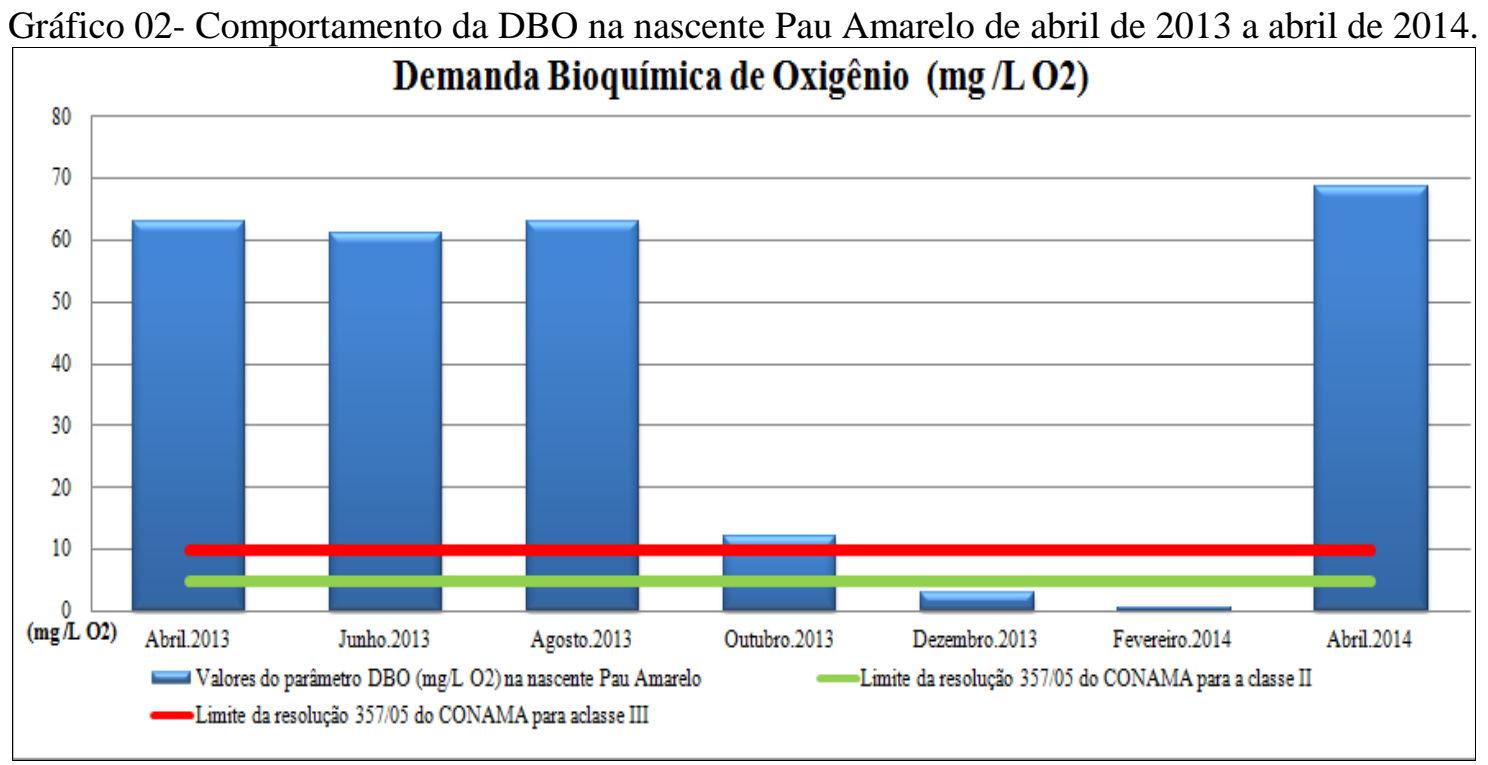

Fonte: Elaborado pelos autores com base em dados da pesquisa.

Comparando os parâmetros OD e DBO, percebe-se que a grande demanda por oxigênio constatada nas três primeiras amostras de DBO alterou profundamente a oxigenação da água no mês de agosto, quando o resultado do OD foi abaixo do exigido para a classe II, indicando poluição, uma vez que houve superávit hídrico. Já nas amostras dos meses de outubro, dezembro e fevereiro, verifica-se que a grande oxigenação da água aconteceu não apenas pelo corpo hídrico ser lótico, mas também por uma provável redução da poluição, uma vez que até mesmo no mês de fevereiro, onde houve déficit hídrico, a oxigenação permaneceu em ótimo estado, com baixíssima demanda por oxigênio. Porém, em abril de 2014, entende-se que a poluição por esgoto pode ter se intensificado, pois a demanda por oxigênio foi a maior apresentada no período em análise.

Outro fator que certamente contribuiu para tal piora, em abril de 2014, tem relação com a grande quantidade de lixo carreado pelas enxurradas provocadas pelas chuvas ocorridas nos três dias anteriores à coleta, quando choveu um total de $89 \mathrm{~mm}$, causando o transporte do lixo doméstico depositado por moradores na cabeceira do vale onde a nascente se localiza. Nesse sentido, embora na maior parte do período em análise a alta demanda por oxigênio não tenha alterado fortemente a oxigenação da água, constata-se uma demanda gravíssima característica de corpos hídricos altamente impactados por esgoto.

Analisando o Gráfico 03, percebe-se que ao longo do período monitorado não houve amostra em que o parâmetro Nitrato tenha estado em conformidade com a Resolução ${ }^{\circ}$ 
357/2005, do CONAMA, para as classes II, III e IV que têm todas como limite máximo 10 mg/L de Nitrato. Com base no Gráfico 03, constata-se que nas amostras dos meses de abril e junho já há mais que o dobro da concentração de Nitrato permitida e que, mesmo havendo uma pequena queda em agosto, o resultado ainda permaneceu alto e fora dos padrões definidos na legislação. Isso indica que o superávit hídrico ocorrido antes da coleta desse mês teve pouca influência na diluição do parâmetro. As amostras dos meses de outubro e dezembro evidenciam progressiva piora que é mantida nas duas últimas amostras com destaque para abril, onde o parâmetro ultrapassou o limite máximo permitido em cinco vezes, comprovando assim poluição orgânica da água coletada, uma vez que a grande quantidade de Nitrato significa poluição por esgoto e representa nutriente para os microrganismos presentes na água, o que favorece o consumo de oxigênio na mesma. Assim, pelo exposto no Gráfico 03, considera-se que há alta concentração de Nitrato presente em todas as amostras e que por essa razão a água proveniente da nascente sofre grave e contínua poluição orgânica, uma vez que o Nitrato é a forma predominante do nitrogênio em águas com avançado estágio de poluição (BRANCO,1993; VON SPERLING,1996).

Gráfico 03- Comportamento do Nitrato na nascente de abril de 2013 a abril de 2014.

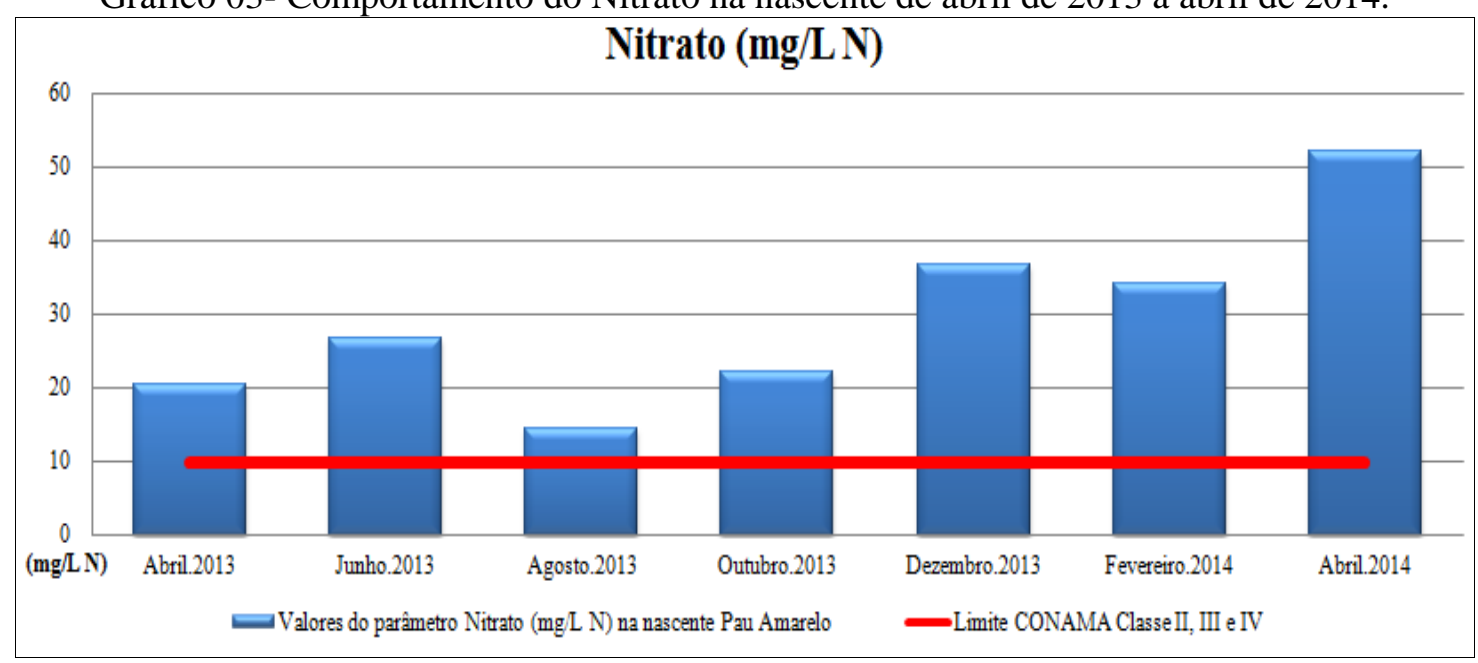

Fonte: Elaborado pelos autores com base em dados da pesquisa.

Para os parâmetros Coliformes Fecais e Totais, optou-se por expressar os resultados das análises no Quadro 04, devido à grande variação e extrapolação dos limites definidos na legislação. 
Quadro 04- Comportamento dos parâmetros Coliformes Fecais e Totais na nascente Pau Amarelo de abril de 2013 a abril de 2014.

\begin{tabular}{|c|c|c|c|c|c|c|c|}
\hline Meses & Abril & Junho & Agosto & Outubro & Dezembro & Fevereiro & Abril \\
\hline $\begin{array}{c}\text { Coliformes fecais } \\
\text { (N.M.P./100ml) }\end{array}$ & $\mathbf{> 1 . 1 0 0}$ & $\mathbf{3 6 0}$ & $\mathbf{6 8 0}$ & $\mathbf{1 6 0 . 0 0 0}$ & $\mathbf{2 8 . 0 0 0}$ & $\mathbf{1 . 7 0 0}$ & $\mathbf{2 . 1 0 0}$ \\
\hline $\begin{array}{c}\text { Limite da classe II } \\
\text { Limite da classe } \\
\text { III }\end{array}$ & 1000 & 1000 & 1000 & 1000 & 1000 & 1000 & 1000 \\
\hline $\begin{array}{c}\text { Coliformes totais } \\
\text { (N.M.P./100ml) }\end{array}$ & $>\mathbf{1 . 1 0 0}$ & $\mathbf{> 1 6 0 . 0 0 0}$ & $\mathbf{1 . 2 0 0}$ & $\mathbf{1 6 0 . 0 0 0}$ & $\mathbf{9 2 . 0 0 0}$ & $\mathbf{2 . 6 0 0}$ & $\mathbf{1 1 . 0 0 0}$ \\
\hline $\begin{array}{c}\text { Limite de } \\
\text { referência }\end{array}$ & 5.000 & 5.000 & 5.000 & 5.000 & 5.000 & 5.000 & 5.000 \\
\hline
\end{tabular}

Fonte: Elaborado pelos autores com base em dados da pesquisa.

Como exposto no Quadro 04, o parâmetro Coliforme Total mostrou grandes variações ao longo do período em análise, apresentando picos altíssimos em junho, outubro e dezembro de 2013, chegando a apresentar, nas amostras de junho e outubro, resultado trinta e duas vezes maior que o limite de referência. Nos demais meses analisados houve resultados mais baixos, porém, de uma forma geral, o período monitorado evidencia grave contaminação que tem origem na poluição por dejetos, uma vez que na maior parte dos meses analisados a amostra apresentou um resultado muito acima do que comumente se encontra em águas que não recebem esgotos. Merece destaque o fato de que no mês de outubro, nos dois dias anteriores à coleta amostral, ocorreram precipitações que somam 16,2mm até mesmo no dia da coleta houve precipitação de $1,2 \mathrm{~mm}$. Porém, mesmo diante dessas condições, houve maior concentração de coliformes totais. Assim, possivelmente, o lixo carreado durante as chuvas impactou mais na qualidade da água do que a possível diluição de contaminantes pelo maior volume de água.

No tocante ao parâmetro Coliforme Fecal fica claro que há uma intensa contaminação da água proveniente da nascente, pois em apenas duas das sete coletas não ocorreu extrapolação do limite da classe II. Isso indica que a presença de patógenos é altíssima na água, uma vez que, segundo Branco (1993), o número de patogênicos tem certa proporcionalidade com o número de coliformes fecais.

Em relação ao parâmetro Condutividade elétrica (CE), foram coletadas amostras em dezembro de 2013 e em fevereiro e abril de 2014. Nas três amostras a alteração do parâmetro foi latente com $992 \mu \mathrm{S} / \mathrm{cm}$ na amostra de dezembro, $884 \mu \mathrm{S} / \mathrm{cm}$ em fevereiro e $1.574 \mu \mathrm{S} / \mathrm{cm}$ em abril. Considerando que segundo Brigante e Espíndola (2003) águas naturais não poluídas dificilmente passam de $100 \mu \mathrm{S} / \mathrm{cm}$, constata-se também, através do parâmetro $\mathrm{CE}$, uma situação de poluição. Os altos níveis de CE encontrados nas amostras de dezembro e fevereiro 
são explicados pelo contínuo lançamento de esgoto na água proveniente da nascente. Já o nível altíssimo encontrado em abril é explicado tanto pelo lançamento de esgoto como pela influência das chuvas ocorridas nos três dias anteriores à coleta as quais somaram $89 \mathrm{~mm}$ e provocaram carreamento de lixo para a área da nascente, causando aumento das partículas em suspensão e considerável piora da qualidade das águas.

\subsubsection{Conclusões das análises dos parâmetros}

A partir das análises dos parâmetros, é possível perceber que o contexto de impactos ambientais que circunda a nascente é gravemente danoso a qualidade da água da mesma. Essa afirmação é corroborada pelos dados que podem ser visualizados no quadro ${ }^{2}$ a seguir construído com base nos resultados das análises da nascente monitorada. É importante destacar que não existe uma correlação direta e proporcional entre todos os parâmetros, a não ser com OD e DBO, mesmo assim, essa correlação deve ser relativizada, pois o corpo hídrico analisado é lótico e isso influência fortemente na oxigenação.

Quadro 05- Resultados das análises dos parâmetros da nascente Pau Amarelo expressos por classe segundo a Resolução no 357/05 do CONAMA.

\begin{tabular}{|l|c|c|c|c|c|c|c|}
\hline \multicolumn{7}{|c|}{ Nascente Pau Amarelo } \\
\hline Parâmetro/mês & Abril & Junho & Agosto & Outubro & Dezembro & Fevereiro & Abril \\
\hline OD & I & I & II & I & I & I & I \\
\hline DBO & IV & IV & IV & IV & I & I & IV \\
\hline Nitrato & IV & IV & IV & IV & IV & IV & IV \\
\hline Coliforme Total & Baixa & Altíssima & Baixa & Altíssima & Altíssima & Baixa & Altíssima \\
\hline Coliforme Fecal & III & II & II & IV & IV & III & III \\
\hline Condutividade & - & - & - & - & Altíssimo & Altíssimo & Altíssimo \\
\hline
\end{tabular}

Fonte: Elaborado pelo autor com base em dados da pesquisa.

Considerando os dados do Quadro 05, percebe-se que na nascente Pau Amarelo $39,28 \%$ das análises estiveram dentro do que determina a legislação para os usos das classes I e II, sendo que a maior parte foi detectada no parâmetro Oxigênio Dissolvido, porém não se

\footnotetext{
${ }^{2}$ Como os parâmetros Coliformes Total e Condutividade Elétrica não possuem limites definidos na legislação, consideramos, para fins desta análise, para o parâmetro Coliforme Total, os seguintes resultados: Baixa concentração quando o resultado foi menor que 5.000, Alta quando foi entre 5.000 e 10.000 e Altíssima de 10.000 em diante. Já para o parâmetro Condutividade Elétrica, consideramos Baixo os resultados inferiores a $100 \mu \mathrm{S} / \mathrm{cm}$, Alto os resultados de 100 a $500 \mu \mathrm{S} / \mathrm{cm}$ e Altíssimo de acima de $500 \mu \mathrm{S} / \mathrm{cm}$.
} 
deve esquecer que tratamos de um corpo hídrico lótico, o que facilita sua oxigenação. $O$ restante dos resultados, em conformidade com a legislação, está em duas amostras nas análises de DBO e em duas de Coliformes Fecais, porém não houve amostra do parâmetro Nitrato dentro da legislação para as classes I e II. As classes III e IV juntas revelam que $60,72 \%$ dos resultados são péssimos, com destaque para o parâmetro Nitrato, que foi enquadrado como classe IV durante todo o período analisado. Outra constatação grave é que $50 \%$ das amostras analisadas foram enquadradas na classe IV, o que evidencia o quadro gravíssimo pelo qual a nascente Pau Amarelo passa, com os parâmetros DBO e Nitrato mostrando grave poluição e o Coliforme Fecal mostrando intensa contaminação, o que foi corroborado pelos parâmetros Coliforme Total e Condutividade Elétrica, que não possuem limites definidos na legislação, mas que se mostraram bastante alterados.

\section{CONSIDERAÇÕES FINAIS E RECOMENDAÇÕES}

A elaboração desta pesquisa partiu da constatação da existência de grave problemática no entorno de uma importante nascente presente no espaço urbano de Garanhuns e por isso objetivou analisar tal problemática verificando de forma qualitativa o grau de impacto a que a nascente estudada está exposta, através da avaliação de elementos-chave na identificação de impactos ambientais e suas consequências sobre a qualidade da nascente e, monitorando a qualidade da água superficial proveniente da nascente bem como analisando os resultados com base na Resolução nº 357/2005 do CONAMA.

Ao analisar a nascente Pau Amarelo através do Índice de Impacto Ambiental em Nascentes - IIAN, constatou-se um contexto de impactos ambientais extremamente grave. Foram mostradas problemáticas que remetem ao total desrespeito à legislação, tanto em nível federal quanto estadual e municipal, gerando impactos ambientais graves como a contaminação das águas e lançamentos de esgotos na nascente e no córrego originado por ela o qual deságua no açude que abastece a cidade. Assim, o poder público municipal aparece como agente de ações contraditórias, pois ao passo que estabelece leis para proteção ambiental, também descumpre essas mesmas leis, tal como acontece com o Plano Diretor Municipal, que tem suas diretrizes e dispositivos de proteção das nascentes completamente ignorados.

O monitoramento da qualidade da água superficial proveniente da nascente e a análise dos resultados dos laudos realizada com base na Resolução n ${ }^{\circ}$ 357/2005 do CONAMA 
apresentaram resultados gravíssimos na nascente monitorada, cuja qualidade da água encontra-se extremamente comprometida. $\mathrm{Na}$ nascente Pau Amarelo há altíssimas concentrações da DBO que, ao longo do período monitorado, chegou a apresentar resultados doze vezes maior que o limite máximo permitido para a classe II. Já o parâmetro Nitrato, em todas as análises esteve em desconformidade com a Resolução nº 357/2005 do CONAMA para as classes II, III e IV, mostrando que a água proveniente da nascente sofre grave e contínua poluição orgânica característica de corpos hídricos impactados por esgoto. Os parâmetros Condutividade Elétrica, Coliformes Totais e Fecais também apresentaram níveis altíssimos com destaque para o Coliforme Fecal, cujos resultados chegaram a ultrapassar cento e sessenta vezes o limite da classe II, indicando altíssima probabilidade da presença de patógenos.

Diante disso, ações voltadas para a extinção dos impactos, recuperação e proteção das áreas da nascente são urgentes, pois constatou-se que os problemas ambientais no entorno da nascente têm natureza histórica e remetem à ausência de atuação, conivência e desrespeito da legislação, principalmente por parte do poder público. Assim, casos como os canais de águas pluviais com ligações clandestinas de esgoto causam problemas ambientais extremamente graves. Todavia, a sua solução não é nenhum mistério e não remete à ausência de aparato legal, mas sim de ações, pois o poder público municipal tem meios de fiscalizar as ligações clandestinas, assim como possui corpo técnico para fazer projetos e adquirir recursos para realizar obras para destinação adequada das águas pluviais, evitando principalmente os fundos de vale e usando métodos de diminuição da velocidade da água para evitar a criação e reativação de voçorocas. Na prática pouco foi feito e quando se fez, foi justamente o contrário, uma vez que a nascente estudada sofre impactos diretos e/ou indiretos por canais de águas pluviais que destinam esgoto de ligações clandestinas, gerando vários processos erosivos oriundos de obras incorretas, assim como contaminação das águas, tal como demonstrado a partir dos resultados da nascente monitorada.

Outra questão que demanda urgência em sua solução é a retirada de moradores de áreas potencialmente perigosas, como é o caso das vertentes do Vale da Liberdade. Nessas vertentes é urgente a retirada dos moradores, a contenção dos processos erosivos, assim como a fiscalização e proibição de aterramentos, devendo a realização de construções também ser proibida nos aterramentos já existentes. Sobre isso o Plano Diretor e o Código Florestal dispõem claramente, uma vez que se trata de Setor de Recuperação Ambiental, APP de encosta e de nascente, cabendo então ao poder público buscar meios de agir, meios inclusive 
já conhecidos e possíveis, como demonstrado quando ocorreu a perda das residências na vertente da Liberdade e a transferência dos moradores para residências construídas através de financiamento de casas populares pela Caixa.

Como sistema ambiental singular que é, ainda mais em Garanhuns, próxima do semiárido, e diante do contexto de degradação atual, a nascente estudada merece e demanda para sua proteção ações que vão além da eliminação dos impactos atuais. Essas ações, sempre que possível, devem ser executadas para aproveitar o potencial ecológico-cultural e de lazer das áreas de nascentes. Nesse sentido, apesar das dificuldades com algumas desapropriações, é perfeitamente possível a criação de um parque na área da nascente Pau Amarelo, que seria uma forma de proteger uma das mais importantes nascentes da cidade que possui grande valor histórico e ambiental, bem como uma forma de criar um espaço ecológico-cultural de lazer, que inclusive tem criação prevista no $11^{\circ}$ artigo do Plano Diretor (GARANHUNS,2008), juntamente com a recuperação da área.

É importante destacar que essas sugestões não são rígidas, podendo haver adaptações, uma vez demandam um esforço significativo para sua realização, porém são sugestões que vão na direção de pensar a cidade como um sistema urbano cujo funcionamento deve favorecer a coletividade, pois a lógica que vigora atualmente gera benefícios para poucos e ônus para a coletividade. Assim, a instituição desse parque pode trazer benefícios ambientais, sociais, culturais e econômicos, através do repasse do ICMS socioambiental ao município.

Por fim, acredita-se que este trabalho possa contribuir com o entendimento das problemáticas analisadas e possa subsidiar ações voltadas para soluções, seja através das reflexões realizadas, dos conhecimentos reunidos a partir do caminho que foi seguido ou mesmo pelos produtos cartográficos gerados que podem ser úteis nos estudos diagnósticos da revisão do Plano Diretor municipal ou mesmo da Bacia do Mundaú.

\section{REFERÊNCIAS}

BRASIL. Ministério da saúde. Portaria no . 518, de 25 de março de 2004. Diário Oficial [da União da República Federativa do Brasil], Brasília, 26 fev. 2012.

BRANDÃO, Carlos Jesus (Org.). Guia nacional de coleta e preservação de amostras: água, sedimento, comunidades aquáticas e efluentes líquidos. Companhia Ambiental do Estado de São Paulo; Brasília: ANA, 2011.

BRANCO, Samuel Murgel. Água: origem, uso e preservação. São Paulo: Moderna, 1993.

BRASIL. Código Florestal. Lei n ${ }^{\circ} 12.651$ de 25 de maio de 2012. 
BRIGATE, J.; ESPÍNDOLA, G. L. E. Liminologia fluvial: um estudo no rio Mogi-Guaçu. São Carlos. RIMA. 278p. 2003.

BRYAN, Kirk. Classification of springs. U.S. Geological Survey, Washington, D.C. The Journal of Geology, v. 27, n. 7, oct.-nov. 1919.

CONAMA,Conselho Nacional de Meio Ambiente. Resolução $\mathbf{n}^{\mathbf{0}}$. 020, de 18 de junho de 1986.Publicação DOU 18/ 06/ 1986 p. 11356-11361. Disponível em: <http://www.mma.gov.br/port/conama/legiabre.cfm?codlegi=43>. Acesso em: 23 mar. 2013.

.Resolução CONAMA $\mathbf{n}^{\mathbf{3}} \mathbf{3 5 7 / 2 0 0 5}$. Disponível em:

<www.mma.conama.gov.br/conama>. Acesso em: 10 out. 2013.

.Resolução $\mathbf{n}^{\circ}$ 302, de 20 de março de 2002. Disponível em:

<http://www.mma.gov.br/conama/>. Acesso em: 20 jul. 2013.

DAVIS, Stanley N. Hidrogeology. New York: 1966.

DEÁK, Csaba, SCHIFFER; Sueli Ramos. O processo de urbanização no Brasil. São Paulo: Editora Universidade de São Paulo, 1999.

FELIPPE, Miguel. F.; MAGALHAES Jr., A. P. Impactos ambientais macroscópicos e qualidade das águas em nascentes de parques municipais em Belo Horizonte-MG. Geografias (UFMG), v. 15, p. 8-23, 2012.

, Miguel F. Caracterização e tipologia de nascentes em unidades de conservação de Belo Horizonte com base em variáveis geomorfológicas, hidrológicas e ambientais. Dissertação (Mestrado em Geografia) - Universidade Federal de Minas Gerais, Belo Horizonte, 2009.

Miguel Fernandes; LAVARINI, Chrystiann; PEIFER, Daniel; DOLABELA, Davi MAGALHÃES JR, Antônio. Espacialização e caracterização das nascentes em unidades de conservação de Belo Horizonte-MG. In: Simpósio Brasileiro de Recursos Hídricos, 2009.

GARANHUNS. Plano Diretor Participativo do Município de Garanhuns-PE. Lei $\mathrm{n}^{\circ} 3620$ de 2008. Secretaria Planejamento. Garanhuns: 2008.

GOMES, P. M.; MELO, C.; VALE, V. S. Avaliação dos impactos ambientais em nascentes na cidade de Uberlândia-MG: análise macroscópica. Sociedade \& Natureza, Uberlândia, 17 (32), jun. 2005.

GUERRA, A. J. T. Guerra, A. T. Novo dicionário geológico-geomorfológico. Rio de Janeiro: Bertrand Brasil, 1997.

A. J. T.; OLIVEIRA, A. ; OLIVEIRA, F. L. ; GONÇALVES, L. F. H. . Mass

Movements in Petrópolis, Brazil. Geography Review, v. 20, p. 34-37, 2007.

GOOGLE, Software Google Earth, 2013.

IBGE, Monografia de Garanhuns. Rio de Janeiro: Serviço Gráfico do IBGE, 1959.

Mapeamento Sistemático disponível

em

<ftp://geoftp.ibge.gov.br/mapeamento_sistematico>. Acesso em: 20 out. 2013.

.Garanhuns.

Disponível

em

<http://cidades.ibge.gov.br/xtras/perfil.php?codmun=260600> Acesso em: 20 de Maio de 2015.

MENDONÇA. Impactos ambientais urbanos. Curitiba: Editora da UFPR, 2004.

PARAGUAÇU, L.; MIRANDA, V.; FELIPPE, M.; MAGALHÃES JR, A. Influência da urbanização na qualidade das nascentes de parques municipais em Belo Horizonte-MG. In: Simpósio Nacional de Geomorfologia, 8., 2010, Recife-PE. Anais.

PINTO, L. V. A.; BOTELHO, S. A.; DAVIDE, A. C.; FERREIRA, E. Estudo das nascentes da bacia hidrográfica do Ribeirão Santa Cruz, Lavras, MG. Scientia Forestalis, n. 65. jun. 2004. 
SOUZA, Marcelo Lopes de. Desafio metropolitano. 3. ed. Rio de Janeiro: Bertrand Brasil, 2010.

TODD, D. K.; MAYS, L. W. Groundwater hydrology. 3. ed. New Jersey: Wiley, 2005.

VALENTE, Osvaldo F.; GOMES, Marcos A. Conservação de nascentes: hidrologia e manejo de bacias hidrográficas de cabeceiras. Viçosa: Aprenda Fácil, 2011.

VON SPERLING, Marcos. Introdução à Qualidade das águas e ao tratamento de esgotos. Belo Horizonte: DESA-UFMG, 1996. (Princípios do Tratamento Biológico de Águas Residuárias, v. 1). 